DOI: $10.32702 / 2307-2105-2021.12 .83$

УДК 657.6:631.11

\title{
Kh. Danylkiv
}

PhD in Economics, Associate Professor of the Department of Finance, Accounting and Analysis, Lviv Polytechnic National University, Ukraine, Lviv

ORCID ID: 0000-0003-1283-6844

\section{O. Sadura}

PhD in Economics, Associate Professor of the Department of Finance, Accounting and Analysis, Lviv Polytechnic National University, Ukraine, Lviv ORCID ID: 0000-0001-7898-9128

O. Vasylyna

PhD in Economics, Associate Professor of the Department of Economy, Lviv National Agrarian University, Ukraine, Lviv ORCID ID: 0000-0003-2124-3792

\section{THE ROLE OF SWOT ANALYSIS IN SUBSTANTIATION PROSPECTS FOR THE DEVELOPMENT OF THE OIL AND GAS PRODUCTION ENTERPRISE}

\author{
Х. П. Данилків, \\ к. е. н., доцент кафедри фінансів, обліку і аналізу, \\ Національний університет «Львівська політехніка», м. Львів, Украӥна \\ О. Б. Садура, \\ к. е. н., доцент кафедри фінансів, обліку і аналізу, \\ Національний університет «Львівська політехніка», м. Львів, Україна \\ О. Р. Василина, \\ к. е. н., доцент кафедри економіки, \\ Львівський національний аграрний університет, м. Львів, Україна

\section{РОЛЬ SWОТ-АНАЛІЗУ В ОБГРУНТУВАННІ ПЕРСПЕКТИВ РОЗВИТКУ ПІДПРИЕМСТВА НАФТОГАЗОВИДОБУВНОЇ ПРОМИСЛОВОСТІ}

One of the most important sectors of the economy, on which depends the efficiency of the entire economic system in the country is the oil industry. Oil and gas production, like no other branch of the economy, creates a large number of jobs and consumes the products of many sectors of the economy. The economic effect of the development of this industry is the multiplier effect of the funds invested in production.

Within the framework of strategic planning, SWOT analysis is considered as a separate stage of evaluation and structuring of information. Its use allowed to systematize the available information on the strengths and weaknesses of the oil and gas industry (advantages and disadvantages), as well as its opportunities and threats (environmental factors, the impact of which will create advantages or potentially hinder market activities). SWOT analysis is an important component of the selection and development of the entity's strategy, as it allows you to assess the internal potential of the enterprise and identify opportunities and threats to the external environment.

The article analyzes several internal and external factors and builds a SWOT analysis of the oil and gas industry enterprise «Borislavnaftogaz», to better understand its financial and economic 
situation and form a strategy for its development. The Boryslavnaftogaz oil and gas company is a unique hydrocarbon facility, one of the largest, oldest, most famous fields in Europe, and one of the centers of world development in the oil industry.

Analyzing the SWOT analysis of Boryslavnaftogaz, we note that the following factors are of the greatest importance: strategy and concept for new fields, exploration, and drilling, concluding contracts for the purchase of long-supply goods where preparatory work for drilling 3 new wells, capital wells directed to the extension of special permits for extraction. The loss of the enterprise (during the analyzed period of 2017-2020), the high degree of depletion of deposits, depreciation of fixed assets - some of the most influential weaknesses and deserve the most attention.

Однією з найважливіших галузей народного господарства, від якої залежить ефективність функціонування всієї системи господарювання в країні є нафтовидобувна галузь. Видобуток нафти $і$ газу як ніяка інша галузь економіки, створює велику кількість робочих місць $i$ споживає продукцію багатьох галузей народного господарства. Економічний ефект від розвитку иієї галузі полягає у мультиплікачійному ефекті коштів, вкладених у видобуток.

В рамках стратегічного планування як окремий етап оцінювання та структурування інформації розглядається SWOT-аналіз. Його використання дало змогу систематизувати наявну інформацію щзодо сильних та слабких сторін нафтогазовидобувної промисловості (переваг і недоліків), а також ї̈ можливостей та загроз (фактори зовнішнього середовища, вплив яких створить переваги або потенційно перешкодить діяльності на ринку). SWOTаналіз $\epsilon$ важливим компонентом вибору та розроблення стратегї суб'єкта господарювання, оскільки дає змогу оцінити внутрішній потенціал підприємства та визначитися з можливостями та загрозами зовнішнього оточення.

У статті проаналізовано ряд внутрішніх та зовнішніх чинників та побудовано SWOT-аналіз підприємства нафтогазовидобувної промисловості «Бориславнафтогаз», для кращзого розуміння його фінансово-економічного становища та формування стратегії їх розвитку. Підприємство нафтогазовидобувної промисловості «Бориславнафтогаз» $е$ унікальним вуглеводневим об'єктом, одним з найбільших, найстаріших, найвідоміших родовищ Європи, одним з центрів світового розвитку нафтопромислової справи.

Проаналізувавши SWOT-аналіз підприємства нафтогазовидобувної промисловості «Бориславнафтогаз» спостерігаємо, щзо найбільше значення мають наступні фактори: стратегія та концепиія щуодо нових родовищ, геологорозвідки та бурових робіт, укладання контрактів на закупівлю товарів довгого постачання де велись підготовчі роботи для буріння 3 нових свердловин, капітальні витрати направленні на продовження спещдозволів на видобування. Збитковість підприємства (протягом аналізованого періоду 2017-2020 рр.), високий ступінь виснаженості родовищ, зношеність основних засобів - одними із найвпливовіших слабких сторін та заслуговують найбільшої уваги.

Key words: SWOT analysis; oil and gas industry; financial and economic situation; internal and external factors; development strategy.

Ключові слава: SWOT-аналіз; нафтогазовидобувна промисловість; фінансово-економічне становище; внутрішні та зовнішні чинники; стратегія розвитку.

Statement of the problem in general and its connection with important scientific or practical tasks. Today, Ukraine's oil and gas complex undoubtedly plays a key role not only in the domestic fuel and energy complex but also in the economy as a whole. Ensuring a sufficient level of development of the oil and gas complex is a necessary condition for the stable development of any country, because, in addition to purely commercial activities, enterprises of this complex play an important social role, providing the population, budget institutions, and utilities with natural gas prices.

In 2020, both in Ukraine and in the world, the macroeconomic situation was characterized by instability, and energy prices - high volatility and a general negative trend. In March 2020, due to the increase in supply due to the failure of negotiations to limit production under OPEC+ and reduced demand due to the introduction of quarantine measures in many countries, prices fell significantly. Subsequently, due to the gradual resumption of economic activity, oil prices resumed growth. Overall, Brent oil prices ranged from \$19 to \$64 per barrel during the year, and Urals oil 
prices, which are closest to domestic oil, ranged from $\$ 20$ to $\$ 62$ per barrel. The average annual oil prices of both grades were $\$ 42 /$ barrel [6].

2020 saw the lowest gas prices in recent years, primarily due to increased supplies of liquefied natural gas from the United States to Europe, combined with reduced consumption through COVID-19. At the same time, prices during the year were characterized by a more pronounced dependence on seasonality. Thus, during the heating season in January-February and October-December, prices were significantly higher than in other months due to seasonal growth in demand.

Due to the collapse of world hydrocarbon prices in the spring of 2020, the reporting year became one of the most difficult for the oil industry of Ukraine. Despite this, in 2020 the production of oil and gas condensate in Ukraine amounted to 2.4 million tons, which corresponds to 2019. Given the state of the domestic economy, the problems and prospects of the modern oil and gas complex of Ukraine are quite relevant [6].

Within the framework of strategic planning, SWOT analysis is considered as a separate stage of evaluation and structuring of information. Its use will allow systematizing the available information on the strengths and weaknesses of the oil and gas industry (advantages and disadvantages), as well as its opportunities and threats (environmental factors, the impact of which will create advantages or potentially hinder market activities). It is an important component of the selection and development of the entity's strategy, as it allows you to assess the internal potential of the enterprise and identify opportunities and threats to the external environment [4].

Analysis of recent research and publications, which initiated the solution of this problem and on which the author relies, the selection of previously unsolved parts of the general problem, which is the subject of this article. Some aspects of the functioning of the oil and gas industry, considered in their work, such domestic scientists as L. Horal, A. Hrytsyk, S. Korol, V. Myroshnychenko, S. Onyshchenko, O. Shapran, V. Shyiko, K. Shtepenko, O. Chervinska, and other. The general method of conducting SWOT-analysis is widely covered by many scientists, in particular, such as L. Lipych, M. Kulynych H. Semenov, O. Yaroshevskaia, L. Shkulipa, M. Pyvovarov, A. Shapovalov, M. Zghurovskyi, K. Perevezra.

The scientific works of these scientists note that the SWOT analysis provides a basis for assessing the effectiveness of the organization, identifying opportunities and threats from the environment to the market environment.

However, despite a large amount of research on selected topics and the wide range of issues considered, several unresolved issues remain, namely in terms of their use in the strategic analysis of the development of agricultural enterprises. The need for new approaches to strategic analysis in this area and several specific aspects require further research and development.

Formulation of the goals of the article (task statement). The article aims to identify external and internal factors that affect the functioning of the oil and gas industry «Borislavnaftogaz», and SWOT-analysis as one of the most common and effective tools for developing development strategies.

Presentation of the main material of the study with a full justification of the obtained scientific results. In recent years, oil and condensate production in Ukraine has stabilized at almost 4 million tons, where the share of BNPR is almost 4\%. Boryslavnaftogaz ranks second among the 6 oil and gas production departments of PJSC Ukrnafta in terms of industrial oil reserves, its share is $20.1 \%$, mostly hard-to-extract oil reserves, fields in late or final stages of development. The main field of the district is the Boryslav oil and gas condensate ozokerite field [5].

NGVU «Borislavnaftogaz» is a unique hydrocarbon facility, one of the largest, oldest, most famous fields in Europe, one of the centers of world development of the oil industry.

The subject of activity of NGVU «Borislavnaftogaz» is the development and operation of oil, gas, and gas condensate fields, preparation for the sale of oil, gas condensate, and gas; construction and overhaul of facilities for production, collection, preparation, transportation, and utilization of oil, gas, condensate, and water in fields; capital and current repairs of oil, gas, water intake, injection wells, work to increase their productivity, other work on dewatering wells, as well as the supply of natural gas at regulated and unregulated tariffs and other profitable activities not prohibited by Ukrainian laws that promote the fulfillment of the main tasks of NGVU. The main activities of the management are the extraction of oil and associated gas extracted from oil wells.

To better understand the financial and economic situation of the Boryslavnaftogaz oil and gas industry, we will analyze several internal and external factors and build a SWOT analysis. At the first stage, we will identify the strengths and weaknesses of NGVU «Borislavnaftogaz» using the following evaluation parameters: finance, marketing, organization, production, personnel management, investment, and innovation (Table 1). 
Table 1.

Identification of strengths and weaknesses of the enterprise of oil and gas industry «Borislavnaftogaz»

\begin{tabular}{|c|c|c|}
\hline Evaluation parameters & Strengths & Weak sides \\
\hline $\begin{array}{c}\text { Finances } \\
\text { (assessment of financial condition, } \\
\text { financial stability of the enterprise, } \\
\text { corporate liquidity, business } \\
\text { profitability, production costs, } \\
\text { capital turnover rate) }\end{array}$ & $\begin{array}{l}\text { financial stability of the enterprise of oil } \\
\text { and gas industry «Borislavnaftogaz». }\end{array}$ & $\begin{array}{l}\text { - the illiquid structure of the } \\
\text { balance sheet of the } \\
\text { Boryslavnaftogaz oil and gas } \\
\text { industry enterprise; } \\
\text { - unprofitable enterprise } \\
\text { (during 2017-2020). }\end{array}$ \\
\hline $\begin{array}{c}\text { Marketing } \\
\text { (strategy, concept, tactics, product } \\
\text { sales, competitors) }\end{array}$ & $\begin{array}{l}\text { - strategy and concept for new deposits, } \\
\text { exploration, and drilling; } \\
\text { - research and development. }\end{array}$ & \\
\hline $\begin{array}{c}\text { Organization } \\
\text { (organizational structure of } \\
\text { management, level of qualification } \\
\text { of workers, interest in development } \\
\text { of the enterprise, interaction } \\
\text { between divisions) }\end{array}$ & $\begin{array}{l}\text { - quality staff; } \\
\text { - staff training and development; } \\
\text { - high level of qualification and persistence } \\
\text { of the management; } \\
\text { - restructuring of the warehouse logistics } \\
\text { function and creation of a centralized } \\
\text { Logistics Department; } \\
\text { - the transformation of the transport } \\
\text { function and the creation of a centralized } \\
\text { Transport Department. }\end{array}$ & \\
\hline $\begin{array}{c}\text { Production } \\
\text { (organization and efficiency of } \\
\text { production, production capacity, } \\
\text { quality and degree of operation of } \\
\text { equipment, quality of finished } \\
\text { products, labor protection in } \\
\text { production) }\end{array}$ & $\begin{array}{l}\text { - products that meet the best world } \\
\text { standards; } \\
\text { - best practice in the field of labor } \\
\text { protection was introduced; } \\
\text { - the corporate motivational program } \\
\text { «Reward for activity in the field of labor } \\
\text { safety» is developed. }\end{array}$ & $\begin{array}{l}\text { the high degree of depletion of } \\
\text { deposits. }\end{array}$ \\
\hline $\begin{array}{c}\text { HR } \\
\text { (recruitment and selection of staff, } \\
\text { training, and development of staff; } \\
\text { staff motivation) }\end{array}$ & $\begin{array}{l}\text { - introduced a system of grades for } \\
\text { managerial and engineering positions of all } \\
\text { structural units and a scheme of salaries } \\
\text { based on grades (the level of wages is now } \\
\text { focused on market indicators, its size has } \\
\text { increased by more than } 30 \% \text {, and } \\
\text { remuneration is tied to employee } \\
\text { performance); } \\
\text { - a monthly bonus for employees } \\
\text { (including KTU) and semi-annual bonus } \\
\text { for managers and ITP (taking into account } \\
\text { corporate results and close connection with } \\
\text { the results of individual KPIs); } \\
\text { - social benefits for employees (at the birth } \\
\text { of a child, large families and families with } \\
\text { children with disabilities, for the burial of } \\
\text { the employee/relatives, relatives of the } \\
\text { employee) }\end{array}$ & \\
\hline $\begin{array}{c}\text { Investments } \\
\text { (expansion of production, licenses, } \\
\text { special permits, the conclusion of } \\
\text { contracts) }\end{array}$ & $\begin{array}{l}\text { - part of last year's capital expenditures } \\
\text { was aimed at extending special permits for } \\
\text { extraction; } \\
\text { - concluding contracts for the purchase of } \\
\text { long-supply goods where preparatory work } \\
\text { was carried out for drilling } 3 \text { new wells. }\end{array}$ & $\begin{array}{l}\text { investments in the } \\
\text { construction of new wells } \\
\text { decreased by } 76 \% \text { (no drilling } \\
\text { was carried out directly) }\end{array}$ \\
\hline $\begin{array}{c}\text { Innovation } \\
\text { (management of enterprise } \\
\text { development, frequency of } \\
\text { introduction of new products and } \\
\text { services in production, degree of } \\
\text { their novelty (insignificant or } \\
\text { cardinal changes), payback periods } \\
\text { of means invested in development } \\
\text { of novelties) }\end{array}$ & & $\begin{array}{l}\text { depreciation of fixed assets } \\
\text { (buildings, structures, } \\
\text { machinery and equipment, } \\
\text { tools) }\end{array}$ \\
\hline
\end{tabular}


At the second stage of SWOT-analysis - market assessment. When assessing market opportunities and threats, we take as a basis the following assessment parameters: sales, economic factor, political and legal factor, demand, natural and environmental factors, scientific and technical factors, socio-cultural factor [3] (Table 2).

Table 2.

Identification of market opportunities and threats of Boryslavnaftogaz oil and gas industry enterprise

\begin{tabular}{|c|c|c|}
\hline Evaluation parameters & Opportunities & Threats \\
\hline $\begin{array}{c}\text { Marketing } \\
\text { (availability of various distribution } \\
\text { networks, product distribution channels } \\
\text { that allow resolving the issue of forming } \\
\text { a sales network, } \\
\text { terms of supply of components and } \\
\text { materials) }\end{array}$ & $\begin{array}{l}\text { increase and increase the } \\
\text { efficiency of production through } \\
\text { the implementation of various } \\
\text { categories of organizational and } \\
\text { technical measures. }\end{array}$ & \\
\hline $\begin{array}{c}\text { Economic factor } \\
\text { (inflation rate, taxation system, financial } \\
\text { and credit policy in the country, changes } \\
\text { in the structure of consumer } \\
\text { consumption) }\end{array}$ & $\begin{array}{l}\text { to remove the restrictive burden, } \\
\text { which will significantly expand } \\
\text { the opportunities for enterprise } \\
\text { development and attract } \\
\text { investment capital. }\end{array}$ & tax debt regularly. \\
\hline $\begin{array}{c}\text { Political and legal factors } \\
\text { (state of legislation regulating economic } \\
\text { activity, consequences of the impact of } \\
\text { foreign policy actions on the } \\
\text { development of markets, state economic } \\
\text { policy) }\end{array}$ & & $\begin{array}{l}\text { quite frequent changes in the legal } \\
\text { framework, as well as a high } \\
\text { degree of contradiction between } \\
\text { existing acts, which hurts the } \\
\text { company. }\end{array}$ \\
\hline $\begin{array}{c}\text { Demand } \\
\text { (market capacity, growth or contraction } \\
\text { rates) }\end{array}$ & & $\begin{array}{l}\text { - transition to more alternative } \\
\text { fuels (falling demand); } \\
\text { - with declining incomes, fewer } \\
\text { oil and gas products are used by } \\
\text { the population. }\end{array}$ \\
\hline $\begin{array}{l}\text { Natural and environmental factors } \\
\text { (state of the environment, level of its } \\
\text { pollution, public attitude to } \\
\text { environmental protection) }\end{array}$ & $\begin{array}{l}\text { - to introduce the best world } \\
\text { practices in the field of } \\
\text { environmental safety; } \\
\text { - take measures that can reduce } \\
\text { the negative impact of } \\
\text { environmental factors. }\end{array}$ & $\begin{array}{l}\text { - growth of gassiness in the city } \\
\text { of Borislav; } \\
\text { - oil manifestations in places of } \\
\text { decommissioning. }\end{array}$ \\
\hline $\begin{array}{l}\text { Scientific and technical factors } \\
\text { (degree of the introduction of new } \\
\text { technologies in industrial production) }\end{array}$ & $\begin{array}{l}\text { - involvement in the operation of } \\
\text { new development facilities; } \\
\text { - introduction of new technologies } \\
\text { in deposits; } \\
\text { - the use of forced liquid } \\
\text { extraction due to the effective } \\
\text { introduction of mechanized } \\
\text { extraction in deposits; } \\
\text { - optimization of capital and } \\
\text { current repairs of promising wells. }\end{array}$ & \\
\hline $\begin{array}{c}\text { Соціально-культурний фактор } \\
\text { (рівень освіти, ставлення людей до } \\
\text { праці) }\end{array}$ & $\begin{array}{l}\text { - improving corporate culture; } \\
\text { - introduction of highly } \\
\text { specialized professional training } \\
\text { courses; } \\
\text { - development of expertise and } \\
\text { knowledge exchange. }\end{array}$ & \\
\hline
\end{tabular}

Having analyzed the strengths and weaknesses, threats, and opportunities of the Boryslavnaftogaz oil and gas industry enterprise, we will assess (probability of impact) how important they are for the activities of the studied enterprise. We will evaluate and include them in the relevant sections of the SWOT analysis (Table 3). 
Table 3.

Influence of factors on the development of the activity of the enterprise of the oil and gas industry «Borislavnaftogaz»

\begin{tabular}{|c|c|c|}
\hline & $\begin{array}{c}\text { Rating } \\
\text { (probability of } \\
\text { impact) }\end{array}$ & Factor \\
\hline \multirow{16}{*}{ Strengths } & 4 & Financial stability of the enterprise \\
\hline & 4 & Strategy and concept for new deposits, exploration, and drilling \\
\hline & 3 & Research and development \\
\hline & 2 & High-quality staff \\
\hline & 2 & Staff training and development \\
\hline & 5 & High level of qualification and perseverance of the management \\
\hline & 4 & $\begin{array}{l}\text { Restructuring of the warehouse logistics function and creation of a centralized } \\
\text { Logistics Department }\end{array}$ \\
\hline & 4 & $\begin{array}{l}\text { Transformation of the transport function and the creation of a centralized } \\
\text { Transport Department }\end{array}$ \\
\hline & 3 & Products that meet the best world standards \\
\hline & 3 & Best practices in the field of labor protection have been introduced \\
\hline & 2 & $\begin{array}{l}\text { Developed corporate motivational program «Reward for activities in the field of } \\
\text { occupational safety» }\end{array}$ \\
\hline & 3 & $\begin{array}{l}\text { The system of grades for managerial and engineering positions of all structural } \\
\text { units and the scheme of salaries based on grades are introduced }\end{array}$ \\
\hline & 3 & Monthly bonus for workers and semi-annual bonus for managers \\
\hline & 3 & Social benefits for employees \\
\hline & 3 & $\begin{array}{l}\text { Capital expenditures are directed to the extension of special permits for } \\
\text { extraction }\end{array}$ \\
\hline & 4 & $\begin{array}{l}\text { Concluding contracts for the purchase of long-supply goods where preparatory } \\
\text { work was carried out for drilling } 3 \text { new wells. }\end{array}$ \\
\hline \multirow{5}{*}{ Weaknesses } & 4 & $\begin{array}{l}\text { The illiquid structure of the balance sheet of the Boryslavnaftogaz oil and gas } \\
\text { industry enterprise }\end{array}$ \\
\hline & 2 & Unprofitable enterprise (during 2017-2020). \\
\hline & 5 & The high degree of depletion of deposits \\
\hline & 4 & $\begin{array}{l}\text { Investments in the construction of new wells decreased by } 76 \% \text { (no drilling was } \\
\text { carried out directly) }\end{array}$ \\
\hline & 4 & $\begin{array}{l}\text { Depreciation of fixed assets (buildings, structures, machinery and equipment, } \\
\text { tools) }\end{array}$ \\
\hline \multirow{11}{*}{ Opportunities } & 3 & $\begin{array}{l}\text { Increasing and increasing the efficiency of production through the } \\
\text { implementation of various categories of organizational and technical measures }\end{array}$ \\
\hline & 1 & $\begin{array}{l}\text { Remove the restrictive burden, which will significantly expand the company's } \\
\text { development opportunities and attract investment capital }\end{array}$ \\
\hline & 1 & Introduce world best practices in the field of environmental safety \\
\hline & 3 & Take measures that can reduce the negative impact of environmental factors \\
\hline & 5 & Commissioning of new development facilities \\
\hline & 5 & Introduction of new technologies in deposits \\
\hline & 3 & $\begin{array}{l}\text { Application of forced liquid extraction due to effective introduction of } \\
\text { mechanized extraction at deposits }\end{array}$ \\
\hline & 4 & Optimization of capital and current repairs of perspective wells \\
\hline & 3 & Improving corporate culture \\
\hline & 2 & Introduction of highly specialized professional training courses \\
\hline & 2 & Development of expertise and knowledge exchange \\
\hline \multirow{7}{*}{ Threats } & 3 & Tax debt regularly \\
\hline & 3 & $\begin{array}{l}\text { Quite frequent changes in the legal framework, as well as a high degree of } \\
\text { inconsistency between existing acts, hurts the company. }\end{array}$ \\
\hline & 3 & Switching to more alternative fuels (falling demand) \\
\hline & 3 & $\begin{array}{l}\text { As the income of the population decreases, fewer oil and gas products are used } \\
\text { by the population }\end{array}$ \\
\hline & 3 & Growth of gassiness in the city of Borislav \\
\hline & 3 & Oil manifestations in places of decommissioning \\
\hline & 4 & The high degree of depletion of deposits \\
\hline
\end{tabular}

We apply the method of positioning each specific opportunity on the matrix of opportunities (Table 4). 
Table 4.

Matrix of Borislavnaftogaz business opportunities

\begin{tabular}{|c|c|c|c|}
\hline \multirow{2}{*}{$\begin{array}{c}\text { Probability } \\
\text { of use }\end{array}$} & \multicolumn{3}{|c|}{ Вплив } \\
\hline & Strong & Moderate & Small \\
\hline High & - & $\begin{array}{l}\text { Application of forced liquid } \\
\text { extraction due to effective } \\
\text { introduction of mechanized } \\
\text { extraction at deposits }\end{array}$ & - \\
\hline Average & $\begin{array}{l}\text { - Increasing and increasing the efficiency } \\
\text { of production through the } \\
\text { implementation of various categories of } \\
\text { organizational and technical measures. } \\
\text { - Optimization of capital and current } \\
\text { repairs of perspective wells. } \\
\text { Introduction of highly specialized } \\
\text { professional training courses. }\end{array}$ & $\begin{array}{l}\text { - Take measures that can reduce } \\
\text { the negative impact of } \\
\text { environmental factors. } \\
\text { - Improving corporate culture. }\end{array}$ & $\begin{array}{l}\text { Introduce world } \\
\text { best practices in the } \\
\text { field of } \\
\text { environmental } \\
\text { safety }\end{array}$ \\
\hline Low & $\begin{array}{l}\text { - Commissioning of new development } \\
\text { facilities. } \\
\text { - Introduction of new technologies in } \\
\text { deposits. } \\
\text { - Development of expertise and } \\
\text { knowledge exchange. }\end{array}$ & $\begin{array}{l}\text { Remove the restrictive tax burden, } \\
\text { which will significantly expand } \\
\text { the company's development } \\
\text { opportunities and attract } \\
\text { investment capital. }\end{array}$ & - \\
\hline
\end{tabular}

We will compile a similar matrix for threat assessment (Table 5).

Table 5.

Matrix of threats to the activity of the enterprise of oil and gas industry «Borislavnaftogaz»

\begin{tabular}{|c|c|c|c|}
\hline \multirow[b]{2}{*}{$\begin{array}{c}\text { Probability of } \\
\text { realization }\end{array}$} & \multicolumn{3}{|c|}{ Possible consequences } \\
\hline & Destructive & Critical condition & $\begin{array}{c}\text { Severe } \\
\text { condition }\end{array}$ \\
\hline High & & $\begin{array}{l}\text { - Oil manifestations in places of decommissioning. } \\
\text { - Growth of gassiness in the city of Borislav. }\end{array}$ & \\
\hline Average & $\begin{array}{l}\text { The high degree } \\
\text { of depletion of } \\
\text { deposits }\end{array}$ & & \\
\hline Low & & $\begin{array}{l}\text { - Falling demand due to the transition to more alternative } \\
\text { fuels. } \\
\text { - With declining incomes, fewer products are used. } \\
\text { - Quite frequent changes in the legal framework. } \\
\text { - Tax debt regularly }\end{array}$ & \\
\hline
\end{tabular}

In the profile table, we will enter the factors, each of which is given an assessment (Table 6). D - integrated assessment, which shows the degree of importance of the factor [1] on the activities of the oil and gas industry «Borislavnaftogaz».

Table 6.

Environment profile of Boryslavnaftogaz oil and gas industry enterprise

\begin{tabular}{|c|c|c|c|c|}
\hline Environmental factor & $\begin{array}{l}\text { Importance for the } \\
\text { industry }(\ll A »)\end{array}$ & $\begin{array}{l}\text { Impact on the } \\
\text { enterprise }(« B »)\end{array}$ & $\begin{array}{l}\text { Direction of } \\
\text { influence } \\
(« \mathrm{C} »)\end{array}$ & $\begin{array}{c}\text { Degree of } \\
\text { importance } \\
(\ll \mathrm{D} »)\end{array}$ \\
\hline \multicolumn{5}{|c|}{ Strengths } \\
\hline 1. Financial stability of the enterprise & 2 & 3 & +1 & +6 \\
\hline $\begin{array}{l}\text { 2. Strategy and concept for new deposits, } \\
\text { exploration, and drilling }\end{array}$ & 4 & 4 & +1 & +9 \\
\hline 3. Research and development & 3 & 3 & +2 & +8 \\
\hline 4. Quality staff & 3 & 3 & +1 & +7 \\
\hline 5. Staff training and development & 2 & 3 & +1 & +6 \\
\hline $\begin{array}{l}\text { 6. High level of qualification and } \\
\text { perseverance of the management }\end{array}$ & 3 & 3 & +2 & +8 \\
\hline $\begin{array}{l}\text { 7. Restructuring of the warehouse logistics } \\
\text { function and creation of a centralized } \\
\text { Logistics Department }\end{array}$ & 3 & 3 & +2 & +8 \\
\hline $\begin{array}{l}\text { 8. Transformation of the transport function } \\
\text { and the creation of a centralized Department } \\
\text { of Transport }\end{array}$ & 3 & 3 & +2 & +8 \\
\hline 9. Products that meet the best world standards & 3 & 3 & +2 & +8 \\
\hline
\end{tabular}




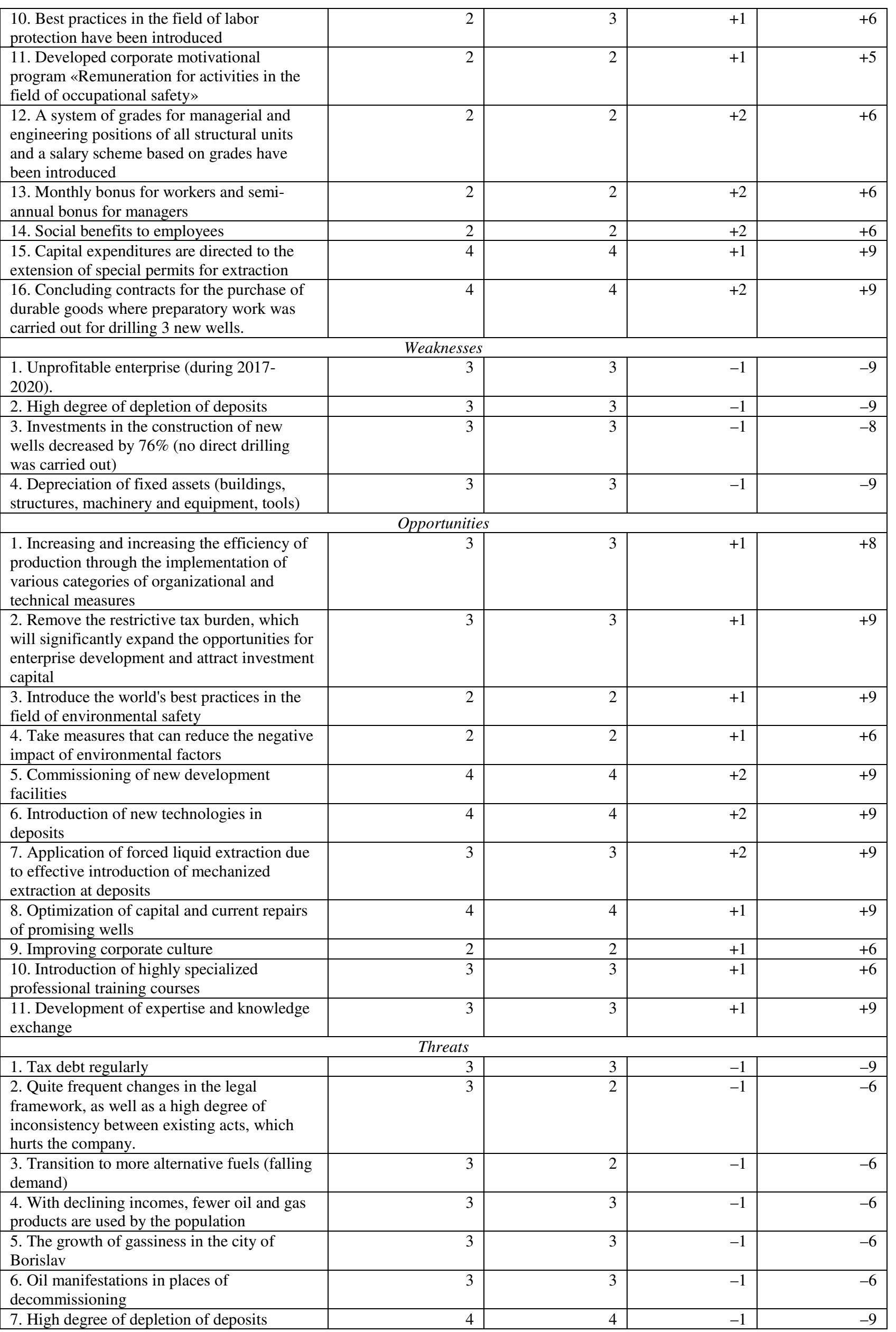

From the results of Table 6, we observe that the most important factors are: strategy and concept for new deposits, exploration, and drilling, contracting for the purchase of long-supply goods where preparations were made for 
drilling 3 new wells, capital expenditures to extend special permits for extraction ( +9 ). The loss of the enterprise (during the analyzed period of 2017-2020), the high degree of depletion of deposits, depreciation of fixed assets (-9) - deserve the most serious attention.

Comparison of strengths and weaknesses with market opportunities and threats has the opportunity to build a SWOT analysis (Table 7).

Table 7.

Matrix of SWOT-analysis of sales of Boryslavnaftogaz oil and gas industry enterprise

\begin{tabular}{|c|c|c|}
\hline & $\begin{array}{l}\text { OPPORTUNITIES } \\
\text { 1. Increasing and increasing the } \\
\text { efficiency of production through the } \\
\text { implementation of various categories } \\
\text { of organizational and technical } \\
\text { measures (+8) } \\
\text { 2. Introduce world best practices in } \\
\text { the field of environmental safety }(+9) \\
\text { 3. Commissioning of new } \\
\text { development facilities }(+9) \\
\text { 4. Introduction of new technologies } \\
\text { in deposits }(+9) \text { of } \\
\text { 5. Optimization of capital and } \\
\text { current repairs of perspective wells } \\
(+9) \text { Introduction of highly } \\
6 \text {. } \\
\text { specialized professional training } \\
\text { courses }(+6) \\
7 \text {. Development of expertise and } \\
\text { knowledge exchange }(+9)\end{array}$ & $\begin{array}{l}\text { THREATS } \\
\text { 1. High degree of depletion of } \\
\text { deposits (-9) } \\
\text { 2. Quite frequent changes in the } \\
\text { legal framework, as well as a high } \\
\text { degree of inconsistency between } \\
\text { existing acts, which hurts the } \\
\text { company (-6) } \\
\text { 3. Transition to more alternative } \\
\text { fuels (falling demand) (-6) } \\
\text { 4. With a decrease in household } \\
\text { income, fewer oil and gas products } \\
\text { are used by the population (-6) } \\
\text { 5. Growth of gassiness in the city } \\
\text { of Borislav (-6) } \\
\text { 6. Oil manifestations in places of } \\
\text { decommissioning (-6) } \\
\text { 7. Tax debt regularly (-9) }\end{array}$ \\
\hline $\begin{array}{l}\text { STRENGTHS } \\
\text { 1. Strategy and concept for new } \\
\text { deposits, exploration, and drilling } \\
(+9) \\
\text { 2. Research and development } \\
(+8) \\
\text { 3. Staff training and development } \\
(+6) \\
\text { 4. High level of qualification and } \\
\text { perseverance of the management } \\
(+8) \\
\text { 5. The system of grades for } \\
\text { managerial and engineering- } \\
\text { technical positions of all structural } \\
\text { units and the scheme of salaries } \\
\text { based on grades (+6) is introduced } \\
6 \text {. Concluding contracts for the } \\
\text { purchase of long-supply goods } \\
\text { where preparatory work was carried } \\
\text { out for drilling } 3 \text { new wells (+9) }\end{array}$ & $\begin{array}{l}\text { Increase production through funding } \\
\text { (invest more in innovation). }\end{array}$ & $\begin{array}{l}\text { Take measures to eliminate the } \\
\text { growth of gassiness in the city of } \\
\text { Borislav. }\end{array}$ \\
\hline $\begin{array}{l}\text { WEAKNESSES } \\
\text { 1. Unprofitable enterprise (during } \\
\text { 2017-2019) (-9). } \\
\text { 2. High degree of depletion of } \\
\text { deposits (-9). } \\
\text { 3. Investments in the construction } \\
\text { of new wells decreased by } 76 \% \text { (no } \\
\text { drilling was carried out directly) (- } \\
\text { 8). } \\
\text { 4. Depreciation of fixed assets } \\
\text { (buildings, structures, machinery } \\
\text { and equipment, tools) (-9). }\end{array}$ & $\begin{array}{l}\text { Due to the depreciation of fixed } \\
\text { assets of the Boryslavnaftogaz oil } \\
\text { and gas industry, the industrial } \\
\text { development of the company is } \\
\text { declining, and a further increase } \\
\text { in production will fall. }\end{array}$ & $\begin{array}{l}\text { The most dangerous is the } \\
\text { depletion of fluids from the } \\
\text { rocks. }\end{array}$ \\
\hline
\end{tabular}

Having developed and analyzed the SWOT analysis, we see that one of the most influential weaknesses is the depreciation of fixed assets and losses of the company during 2017-2020, respectively, we develop proposals to improve the use of fixed assets and profitability.

Conclusions from this study and prospects for further exploration in this direction. Conclusions from this study and prospects for further exploration in this direction. After analyzing the SWOT analysis, we see that the most 
important factors are: strategy and concept for new deposits, exploration, and drilling, contracting for the purchase of long-supply goods where preparations were made for drilling 3 new wells, capital expenditures to extend special permits for extraction. The loss of the enterprise (during the analyzed period of 2017-2020), the high degree of depletion of deposits, depreciation of fixed assets - some of the most influential weaknesses and deserve the most attention.

\section{Список літератури.}

1.Григорук П. М. Методи побудови інтегрального показника. Бізнес Інформ. Економіка. Серія: Економіко-математичне моделювання. 2012. № 4. С. 34-38.

2. Ліпич Л., Кулинич M. SWOT-аналіз центрів відповідальності в контексті управлінського обліку. Вісник Хмельницького національного університету. 2009. № 5. Т. 3. С. 226-228.

3.Danylkiv K., Demchyshak N. B., Hembarska N. SWOT analysis as a tool for providing economic security of insurance companies. Новая Экономика. Спецвипуск. 2021. С. 236-244.

4.Danylkiv K., Sadura O. SWOT analysis as a tool for determining a small entrepreneurial structure development strategy. Інноваційна економіка. 2021. № 3/4 (87). С. 59-66.

5.ПАТ Укрнафта. URL: https://www.ukrnafta.com/ (дата звернення 11.12.2021).

6.Нафтогазова асоціація України. URL: http://oilers.org.ua/uk (дата звернення 11.12.2021).

\section{References.}

1.Hryhoruk, P.M. (2012), "Methods of constructing an integrated indicator", Biznes Inform. Ekonomika. Seriia: Ekonomiko-matematychne modeliuvannia, vol. 4, pp. 34-38.

2.Lipych, L. and Kulynych, M. (2009), "SWOT-analysis of responsibility centers in the context of management accounting”, Visnyk Khmelnytskoho natsionalnoho universytetu, vol. 5(3), pp. 226-228.

3.Danylkiv, K., Demchyshak, N. B. and Hembarska, N. (2021), "SWOT analysis as a tool for providing economic security of insurance companies", Novaia Ekonomyka. Spetsvypusk, pp. 236-244.

4.Danylkiv, K. and Sadura, O. (2021), "SWOT analysis as a tool for determining a small entrepreneurial structure development strategy", Innovatsiina ekonomika, vol. 3/4 (87), pp. 59-66. 2021).

5. The official site of the PJSC Ukrnafta (2021), available at: https://www.ukrnafta.com/ (Accessed 11 December

6. The official site of the Oil and Gas Association of Ukraine. (2021), available at: http://oilers.org.ua/uk (Accessed 11 December 2021). 